Annals of Plant Sciences

\title{
Ethno-botanical study of wild edible fruits consumed by the people of Lakhimpur district of Assam, India.
}

Dharitri Borgohain

Department of Botany, North Lakhimpur College (Autonomous), Lakhimpur - 787031, Assam, India.

Received: 9/17/2017; Accepted: 9/28/2017

\begin{abstract}
The present study deals with the identification, ethno-botanical exploration, documentation and popularization of wild edible fruits consumed by the people of Lakhimpur district of Assam, India. Fruits are the chief sources of essential minerals, protein, carbohydrates, fiber, vitamin C, sugar, water and possess tremendous medicinal value. Fruits play an important role in maintaining a well-balanced weight loss diet and healthy living. During the study period, several field trips were conducted in different seasons and the plants were identified by consulting relevant scientific literatures. In this paper, a total of 48 wild edible fruits belonging to 25 families were recorded along with their local names, scientific name, family, time of availability, taste and uses. Further, emphasize should be given in order to maintain and improve this important source of food supply for their conservation for human welfare.
\end{abstract}

Keywords: Ethno-botany, Medicinal value, Wild edible fruits.

\section{Introduction}

Since time immemorial, wild edible fruits have been playing an indispensable part in supplementing the diet of the people. But with the advent of many exotic fruits, the dependence and popularity of these fruits has gradually declined. In tribal areas, many people still use them extensively as a supplement to their basic food requirement and even preserve for use during periods of food scarcity. Poor people living in the rural areas also depend on these wild edible fruits as an income source for their livelihood.

Wild edible fruits are rich sources of vitamin C, sugar, fiber, minerals and water. They provide fibers which prevent constipation. The edible fruits having nutritional food value provide minerals like sodium, potassium, magnesium, iron, calcium and phosphorus. Since, fruits contain low calorie content, therefore plays a vital role in weight loss and nutrition. Wild fruits are locally available, inexpensive and possess high nutritive value. They have a great socio-economic significance because of their food and medicinal property. Apart from their traditional use of food, wild fruits are widely used in different formulations of Indian folk medicine, fodder and for performing rituals and other functions. They can also be used as remedy for various diseases. Consumption of these fruits reduces the risks from several diseases like diabetes, cancer, neurodegenerative ailment and coronary heart disease (Brahma et al., 2013). Assam constitutes different ethnic communities and tribes. Wild fruits are mainly consumed by the rural and tribal people of different localities of Assam.

People are mostly dependent on various natural resources for their daily requirement and utilize varieties of wild plants as their food both for nutrition and medicinal purposes. Mostly, these wild plants include herbs, shrubs and trees which are used either as vegetables or as fruits. Majority of the fruits are eaten raw when ripe or processed which help to compensate the day-to-day requirement of calories. Generally, the sweetish pulp or the fleshy palatable pericarps of the ripe berries or drupes are consumed. There have been several reports on wild edible fruits done by Upadhye et al., (1994), Wehmer (1996), Bist and Sharma (2005), Sankaram et al., (2006),

\section{*Corresponding Author:}

Dr. Dharitri Borgohain,

North Lakhimpur College, Khelmati-14,

Lakhimpur, Assam, India.

E-mail: dharitri.48@gmail.com
Nitzela et al., (2007), Mengistu and Hager (2008) and Rashid et al., (2008).

\section{Area of study}

Lakhimpur district is bounded by latitude $27^{\circ} 20^{\prime} \mathrm{N}$ and longitude $94^{\circ} 15^{\prime} \mathrm{E}$. The total area of the district is approximately $2,277 \mathrm{~km}^{2}$. It is bounded by Papumpare district of Arunachal Pradesh to the north, Dhemaji district to the east, Jorhat district to the south and Sonitpur district to the west. It has a unique climatic pattern, and average rainfall of $263.3 \mathrm{~mm}$ annually with high humidity $(68 \%)$ prevailing almost throughout the year in the district (http://lakhimpur.nic.in/html). This typical climate results in rich evergreen vegetation with dense forest areas suitable for growth of a large number of wild plant species.

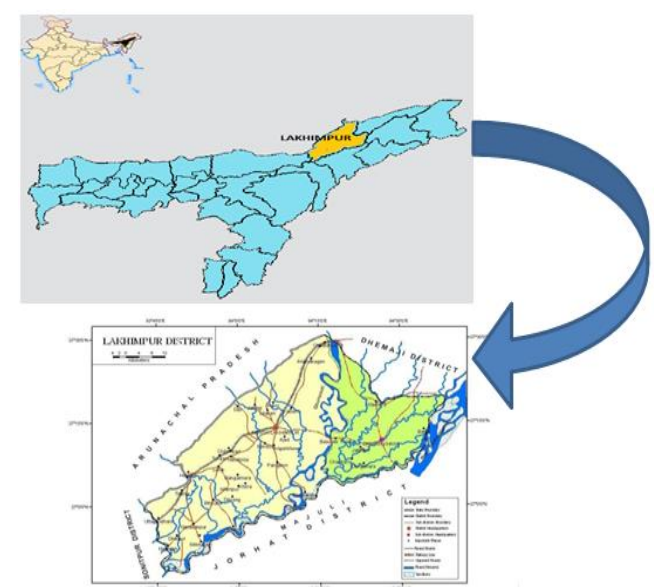

Figure 1. Map showing the study area.

\section{Materials and Methods}

The study was undertaken during 2015-2016 in different seasons by conducting several field trips in different remote places of Lakhimpur district, Assam. In order to assess the traditional knowledge on wild edible fruits, frequent interactions and discussions were made with the local vegetable vendors, villagers, including farmers, herdsmen, shepherds and housewives. Questionnaires 
were done for the collection of data such as local name, time of availability, taste and their mode of uses.

During survey, live specimens along with photographs of all the collected wild edible fruits were taken for local identification and the indigenous knowledge received from them was noted down. The wild fruit plants were identified with the help of local people and referring relevant scientific literatures which includes Hooker (1872-1877); Cooke (1967); Singh and Karthikeyan (2000), Singh et al., (2001) and Yadav and Sardesai (2002).

\section{Results and Discussion}

In the present investigation, a total of 48 wild edible fruits belonging to 25 families were reported along with their local name, scientific name, family, time of availability, taste and uses (Table - 1). Most of these wild fruits have very rich nutritive value. Some of them also possess medicinal properties. Majority of the fruits are eaten as raw when ripe, few are taken as vegetables and pickles.

This study deals with the identification, ethno-botanical exploration and documentation of wild edible fruits with respect to food value available in Lakhimpur district, Assam.
Fruits are considered as nature's gift to mankind and are not only delicious and refreshing but also constitute a major part of daily food intake. Therefore, special attention should be paid to them in order to conserve this important source of food supply. Overexploitation of wild areas due to deforestation and lack of popularity has resulted in declining of these plants and many are nearing extinction. Therefore, mass attention is urgently needed to preserve and popularize these wild edible fruits among the people. Further, the indigenous traditional knowledge about the uses of these wild fruits is valuable and research on its nutritional analysis and their medicinal properties is required for near future.

\section{Conclusion}

Wild fruits play a significant role in providing nutrition to people of rural and tribal communities since they are an excellent source of various vitamins, carbohydrates, proteins, fibers, minerals besides medicinal value. Incorporation of these wild fruit plants in commercial crop plants will improve the economy in tribal areas and food deficiency. The present study would contribute to the database of traditional knowledge of wild fruits as food and also educate the younger generation about its ethno-botanical importance. Furthermore, a scientific investigation of wild edible fruits is necessary in order to assess the potentiality which would be cultivated and utilized as a source of food supply for an ever-increasing population.

Table 1. List of wild edible fruits available in Lakhimpur district of Assam, India.

\begin{tabular}{|c|c|c|c|c|c|c|}
\hline S. No. & Local Name & Scientific Name & Family & Taste & $\begin{array}{c}\text { Time of } \\
\text { availability }\end{array}$ & Uses \\
\hline 1 & Ahom bogori & Prunus persica (L.) Stokes & Rosaceae & Sweet & \multirow{2}{*}{$\begin{array}{l}\text { Mar-June } \\
\text { May-Nov }\end{array}$} & Ripen fruits are eaten raw. \\
\hline 2 & Amlokhi & Phyllanthus emblica L. & Euphorbiaceae & Sour/ astringent & & $\begin{array}{l}\text { Fruits are eaten raw or dried and also } \\
\text { used in pickles. }\end{array}$ \\
\hline 3 & Atlas & Annona reticulata $\mathrm{L}$. & Annonaceae & Sandy Sweet & Nov-Dec & Fruits are eaten raw. \\
\hline 4 & Bel & Aegle marmelos (L.) Corr. Serr. & Rutaceae & Sweet & Feb- June & $\begin{array}{l}\text { Fruits are eaten raw and used in stomach } \\
\text { trouble, constipation. }\end{array}$ \\
\hline 5 & Bet & Calamus tenuis Roxb. & Arecaceae & \multirow{3}{*}{$\begin{array}{l}\text { Astringent } \\
\text { Almond } \\
\text { taste/ astringent } \\
\text { Slightly bitter }\end{array}$} & April-Dec & Ripen fruits are eaten raw. \\
\hline 6 & Bhumura & Terminalia bellirica Roxb. & Combretaceae & & Dec-Feb & $\begin{array}{l}\text { Fruits are eaten raw. Highly medicinal } \\
\text { and used in the preparation of 'Trifola'. }\end{array}$ \\
\hline 7 & Boga bhet & Nymphaea nouchali Burm. f. & Nymphaeaceae & & May-Oct & Fruits are eaten raw. \\
\hline 8 & Bogori & Zisyphus mauritiana Lam. & Rhamnaceae & Sweetish sour & Dec-Feb & $\begin{array}{l}\text { Fruits are eaten fresh. Pickles, jelly can be } \\
\text { prepared }\end{array}$ \\
\hline 9 & Bohot & Artocarpus lacucha Buch. -Ham. & Moraceae & Sweet & May-July & Fruits are eaten raw. \\
\hline 10 & Bokul & Mimusops elengi Roxb. & Sapotaceae & Sandy sweet & Feb-Sept & Ripen fruits are eaten raw. \\
\hline 11 & Bor thekera & Garinia pedunculata Roxb. & Clusiaceae & Sour & May-July & $\begin{array}{l}\text { Ripen fruits are first dried and then eaten } \\
\text { with curries or as pickles. }\end{array}$ \\
\hline 12 & Dimoru & Ficus racemosa $\mathrm{L}$. & Moraceae & Sweet & April-July & Ripen fruits are eaten raw. \\
\hline 13 & Futkola & Melastoma malabathricum $\mathrm{L}$. & Melastomataceae & Sweet & Nov-Jan & Fruits are eaten raw. \\
\hline 14 & Gul nemu & Citrus aurantifolia (Christen) Swing. & Rutaceae & Sour & May-Nov & Fruits are eaten raw or as pickles. \\
\hline 15 & Hati bhekuri & Solanum torvum Swartz. & Solanaceae & Bitter & May-Nov & Young fruits are eaten cooked. \\
\hline 16 & $\begin{array}{l}\text { Humthira } \\
\text { tenga }\end{array}$ & Citrus reticulata Blanco. & Rutaceae & Sweetish sour & Dec-Feb & Mature fruits are eaten raw. \\
\hline 17 & Jetulipoka & Rubus ellipticus Smith. & Rosaceae & Sweet & Sept- Mar & $\begin{array}{l}\text { Ripe fruit smells sweets and is very tasty, } \\
\text { eaten with must relish. }\end{array}$ \\
\hline 18 & Jolphai & Elaeocarpus floribundus $\mathrm{Bl}$. & Elaeocarpaceae & Sour & Oct-Jan & Fruits are eaten raw or as pickles. \\
\hline 19 & Jora tenga & Citrus medica $\mathrm{L}$. & Rutaceae & Sour & Sept-Nov & Fruits are eaten raw. \\
\hline 20 & Kau thekera & Garcinia cowa Roxb. & Clusiaceae & Sour & June-July & $\begin{array}{l}\text { Ripen fruits are first dried and then eaten } \\
\text { with curries or as pickle. }\end{array}$ \\
\hline 21 & Kola jamu & Sysygium cumini (L.) Skeels. & Myrtaceae & Sweet & June-July & Ripen fruits are eaten raw. \\
\hline 22 & Kordoi & Averrhoa bilimbi $\mathrm{L}$. & Oxalidaceae & Sour & Oct-Mar & $\begin{array}{l}\text { Fleshy fruits are eaten raw. Pickles, jelly } \\
\text { can be prepared. It is considered } \\
\text { medicinal and given to jaundice patient. }\end{array}$ \\
\hline 23 & Kothal & Artocarpus beteropbyllus Lamk. & Moraceae & Sweet & Mar-Aug & Ripen fruits are eaten raw. \\
\hline 24 & Kunduli & Coccinia grandis (L.) Voigt. & Cucurbitaceae & Slightly sour & $\begin{array}{l}\text { Throughout the } \\
\text { year. }\end{array}$ & Young fruits are eaten as vegetables. \\
\hline 25 & Kutkura & Menya spinosa Roxb. ex Link. & Rubiaceae & Sweetish sour & Oct-Dec & Ripen dried fruits are edible. \\
\hline 26 & Leteku & Baccaurea ramiflora Lour. & Euphorbiaceae & Sweetish sour & May- July & Ripen fruits are eaten raw. \\
\hline 27 & $\begin{array}{l}\text { Mamoi/ } \\
\text { Mumai } \\
\text { tamul }\end{array}$ & Pinanga gracilis $\mathrm{Bl}$. & Arecaceae & Astringent & Mar-June & Ripen fruits are eaten raw. \\
\hline 28 & Mirika tenga & $\begin{array}{l}\text { Elaeagnus caudata Schltdl. ex } \\
\text { Momiy. }\end{array}$ & Elaeagnaceae & Sour & April-May & Ripen fruits are eaten raw or as pickles. \\
\hline
\end{tabular}




\begin{tabular}{|c|c|c|c|c|c|c|}
\hline 29 & Noga tenga & Myrica esculenta Buch. -Ham. & Myricaceae & Sour & April-Jun & Ripen fruits are eaten raw or as pickle. \\
\hline 30 & Nora bogori & Prunus domestica $\mathrm{L}$. & Rosaceae & Sweetish Sour & Jan-May & $\begin{array}{l}\text { Ripe fruit is eaten with delicacy, either } \\
\text { raw or as pickles. }\end{array}$ \\
\hline 31 & Nuni & Morus alba L. & Moraceae & Sweet & Jan-Feb & Ripen fruits are eaten raw. \\
\hline 32 & Omora & Spondias pinnata (L.f.) Kurz. & Anacardiaceae & $\begin{array}{l}\text { Sour, slightly } \\
\text { bitter }\end{array}$ & Sept-Dec & Fruits are eaten raw. \\
\hline 33 & Outenga & Dillenia indica $\mathrm{L}$. & Dilleniaceae & Sour & July- Dec & $\begin{array}{l}\text { Fruit is eaten raw or cooked as vegetable. } \\
\text { Pickles jams etc. are also prepared. }\end{array}$ \\
\hline 34 & Pani jamu & Sysygium malaccense & Myrtaceae & Sweet & June- July & Ripe fruits are eaten raw. \\
\hline 35 & $\begin{array}{l}\text { Pokmou/ } \\
\text { Kopal futa }\end{array}$ & Physalis minima $\mathrm{L}$. & Solanaceae & Sweet & Mar- Sept & Mature fruits are eaten raw. \\
\hline 36 & Poniol & $\begin{array}{l}\text { Flacourtia jangomas (Lour.) } \\
\text { Raeusch }\end{array}$ & Salicaceae & Sweet & May- July & Ripe fruits are eaten raw. \\
\hline 37 & Pora amlokhi & Phyllanthus acidus (L.) Skeels. & Euphorbiaceae & Astringent & June- July & Ripen fruits are eaten raw or as pickle. \\
\hline 38 & Robab tenga & Citrus maxima (Burm) Osbeck. & Rutaceae & Sweetish sour & Winter & $\begin{array}{l}\text { Ripen fruits are eaten raw. } \\
\text { Fruits are eaten fresh as chutney, squash }\end{array}$ \\
\hline 39 & Rohdoi & Averrboa carambola $\mathrm{L}$. & Oxalidaceae & Sweet & Nov- Jan & $\begin{array}{l}\text { and also considered medicinal for liver } \\
\text { trouble. }\end{array}$ \\
\hline 40 & Rupohi thekera & Garcinia lanceifolia Roxb. & Clusiaceae & Sour & Feb- July & $\begin{array}{l}\text { Ripe fruits are eaten with vegetables. } \\
\text { Pickles can be prepared. The fruit is } \\
\text { highly medicinal. }\end{array}$ \\
\hline 41 & Silikha & Terminalia chebula Retz. & Combretaceae & $\begin{array}{l}\text { Bitter/ } \\
\text { astringent }\end{array}$ & Oct- Dec & $\begin{array}{l}\text { Highly medicinal, fresh or dried fruits are } \\
\text { chewed after meal as digestive. }\end{array}$ \\
\hline 42 & Siral & Cucumis melo L. & Cucurbitaceae & Sandy sweet & July- Oct & Mature fruits are eaten raw. \\
\hline 43 & Sonaru & Cassia fistula $\mathrm{L}$. & Fabaceae & Sweet & Dec- Feb & Fruits are eaten raw. \\
\hline 44 & Tenga mora & Hibiscus subdarifa $\mathrm{L}$. & Malvaceae & Sour & Winter & $\begin{array}{l}\text { Fruits are eaten raw. Jam, jelly, pickles } \\
\text { can be prepared from ripe fruits. }\end{array}$ \\
\hline 45 & Tepor tenga & Garcinia xanthochymus Hook. f. & Clusiaceae & Sour & May-July & $\begin{array}{l}\text { Ripe fruits are eaten raw or cooked with } \\
\text { other vegetables. Pickles can also be } \\
\text { prepared. }\end{array}$ \\
\hline 46 & Teteli & Tamarindus indica $\mathrm{L}$. & Fabaceae & $\begin{array}{l}\text { Sour, } \\
\text { sweet }\end{array}$ & Nov- Feb & $\begin{array}{l}\text { Unripe and ripe fruits are eaten raw. Used } \\
\text { to prepare jelly, pickles. }\end{array}$ \\
\hline 47 & Thereju & Prunus jenkinsii Hook f. \& Th. & Rosaceae & $\begin{array}{l}\text { Sweetish } \\
\text { Sour }\end{array}$ & Dec-Mar & Ripen fruits are eaten raw. \\
\hline 48 & Tita bhekuri & Solanum indicum $\mathrm{L}$. & Solanaceae & Bitter & May-Nov & $\begin{array}{l}\text { Fruits are eaten fried as vegetable and } \\
\text { considered medicinal for worm infection } \\
\text { and skin diseases. }\end{array}$ \\
\hline
\end{tabular}

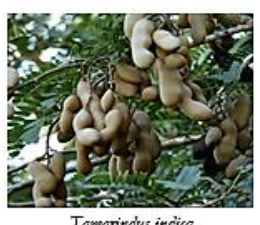

Tamarisades incica
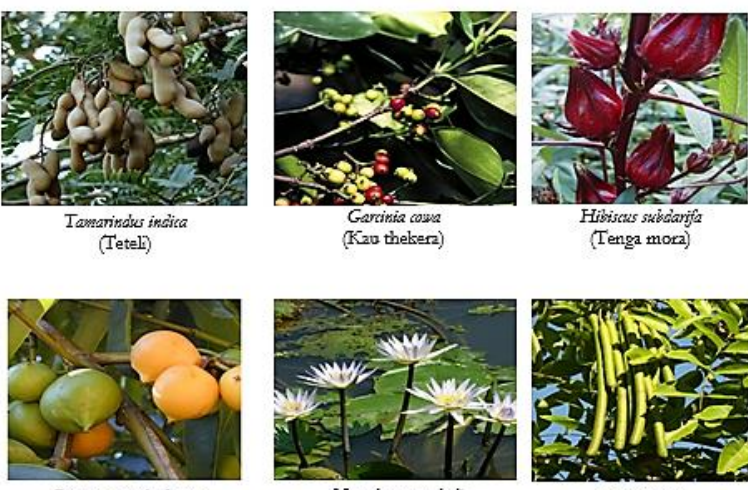

Garcinia seanthocbyme

(Tepor tenga)

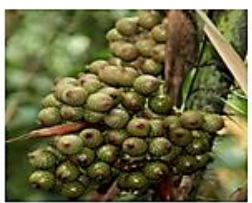

Calomess sen

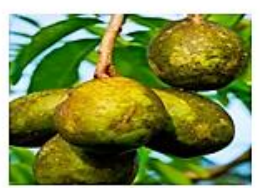

Sponcias pismata
(Omora)

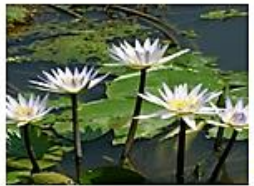

Numbinaza nowchat

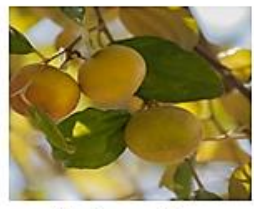

Ziviphes maxition

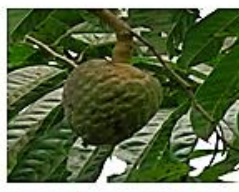

Amoma reticulata

(Atlas)

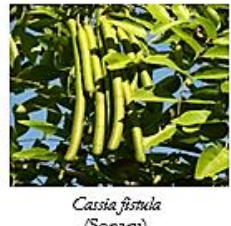

Cassiaftstula
(Sonaru)

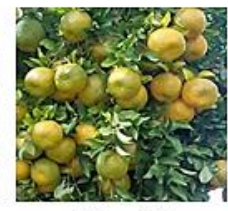

Cinus resticulas

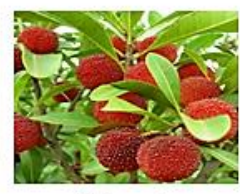

Myrica escelenta
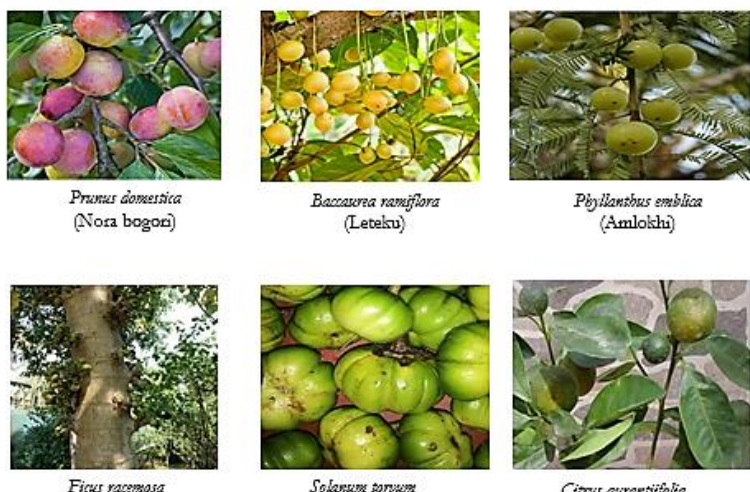

Solvenum sorvese
(Hati bhekun)

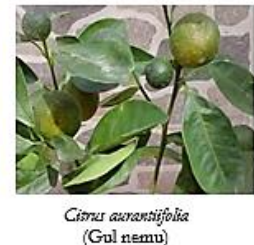

(Dimors)
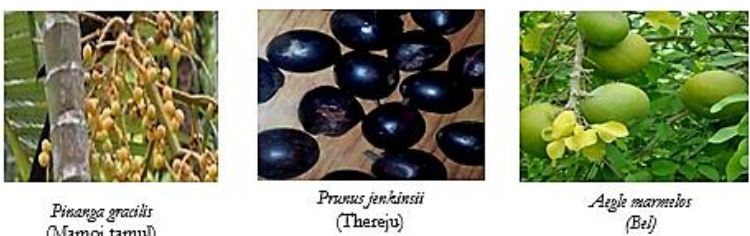

Pinorga grailis
(Mamoi tamul)

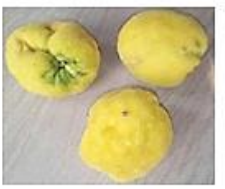

Arsocarpes lacsecha

(Bohot)

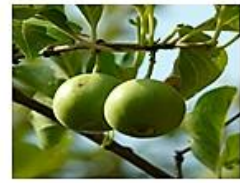

Mergya sainosa (Kurtkura)

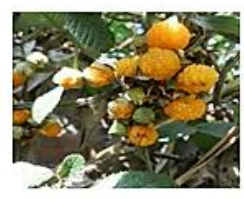

Rubues ellipticus
(Jetulipolas) 


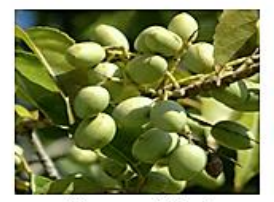

Elarocappos floriberd
(Jolphai)
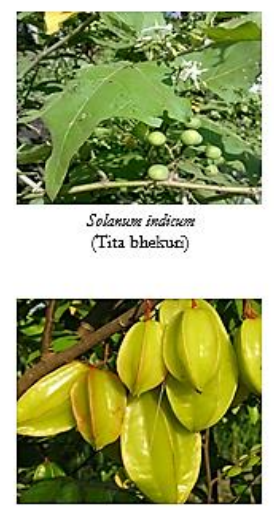

Atembaa bilimbir
(Kordoi)

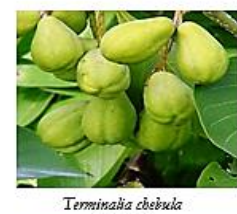

(Slitisha)

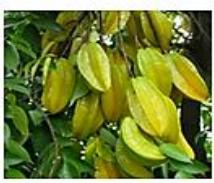

Avembac carambiola
(Rohdoi)

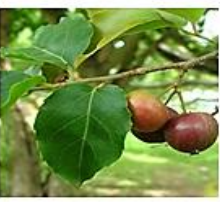

Flacowrsiajangormar
(Poriol)

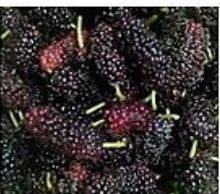

Mones aba
(Nuni)

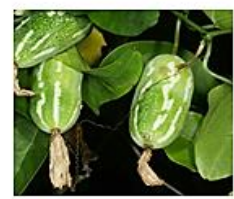

Coccinia grandis
(Kunduli)

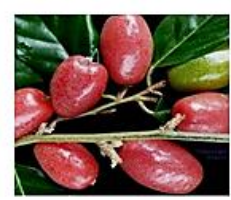

Elasagrus carciata
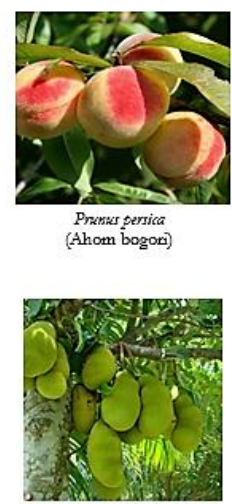

Artocappes hetergopbyilies

(Kothal)

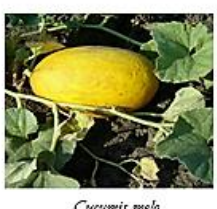

Ckecwuis mel
(Siral)
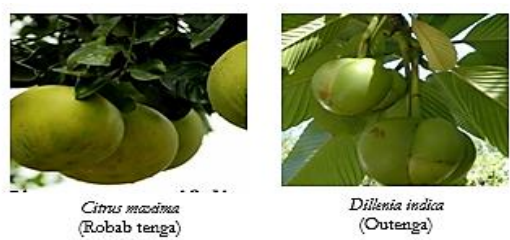

Dillemia irdica
(Outenga)

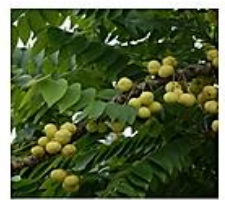

Pbiliansbows acides (Pora amlokhi)

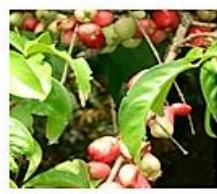

Sjygiver makacest
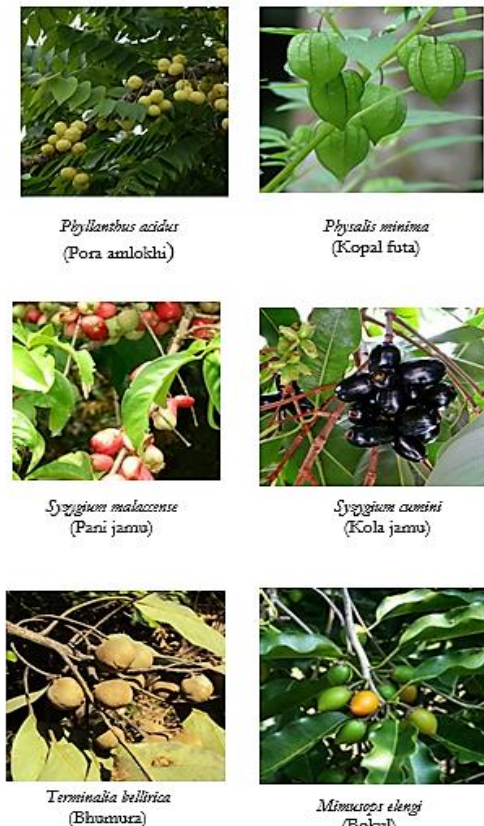

(Kopal futa)

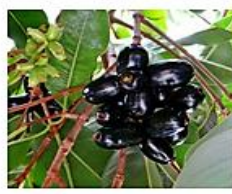

Syspisum cumsini

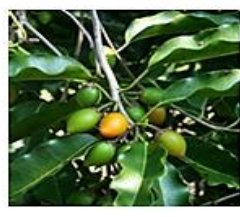

Mimusops elengi
(Bokul)

\section{Acknowledgement}

The author is thankful to all the local people of different localities of the study area for their information, support and help in carrying out of the field studies.

\section{References}

1. Bist HS and Sharma SD, International Symposium on temperate zone fruits in the tropics and subtropics. ISSHS acta Horticulturae, 6 (2005): 696.

2. Brahma S, Narzary $\mathrm{H}$ and Basumatary S, Wild Edible fruits of Kokrajhar District of Assam, North East India. Asian Journal of Plant Science and Research, 3.6. (2013): 95-100.

3. Cooke T, The Flora of the Presidency of Bombay, Botanical Survey of India, Calcutta, 1-3 (1967).

4. Hooker JD, The Flora of British India, London. 1-7 (18721877).

5. Mengistu $\mathrm{F}$ and Hager $\mathrm{H}$, Ethnobotany Research and Applications, 6 (2008): 487-502.

6. Nitzela M, Nitzela G, Tianb Q, Steven S and Konczaka I, Native Australian Innovative food science and emerging tecnologies, 8.3 (2007): 339-346

7. Rashid A, Anand VK and Serwar J, International Journal of Botany, 4.2 (2008): 219- 224.

8. Sankaram M, Prakash J, Singh NP and Suklabaidya A, Wild edible fruits of Tripura, Natural product radiance, 5.4 (2006): 302-305.

9. Singh NP and Karthikeyan S, Flora of Maharashtra State Dicotyledones, Botanical Survey of India, Calcutta, 1 (2000)

10. Singh NP, Lakshminarasimhan $\mathrm{P}$, Karthikeyan $\mathrm{S}$ and Prasanna PV, Flora of Maharashtra State - Dicotyledones, Botanical Survey of India, Calcutta, 2 (2001).

11. Upadhye A, Kumbhojkar MS and Vartak VD, Ethnomedico botanical studies in western Maharashtra, Ethnobotany, 6 (1994): 25-31.

12. Wehmer AS, The nutrient composition of some edible wild fruits found in the Transvaal, South African journal of nutrition, 40 (1996): 1102-1104.

13. Yadav SR and Sardesai MM, Flora of Kolhapur District, Pub. Shivaji university, Kolhapur, (2002)

\section{Cite this article as:}

Dharitri Borgohain. Ethno-botanical study of wild edible fruits consumed by the people of Lakhimpur district of Assam, India Annals of Plant Sciences 6.11 (2017) pp. 1732-1735.

doi: http://dx.doi.org/10.21746/aps.2017.6.11.3 